\title{
Ochna kirkii Oliv: Pharmacognostical Evaluation, Phytochemical Screening, and Total Phenolic Content
}

\author{
Endang Hanani*, Vivi Anggia, Ike Nurvita Amalina
}

Endang Hanani*, Vivi Anggia, Ike Nurvita Amalina

\section{Department of Pharmacognosy and} Phytochemistry, Faculty of Pharmacy and Sciences, Universitas Muhammadiyah Prof. DR. HAMKA

J. Delima II/IV Klender, Jakarta 13460, INDONESIA.

\section{Correspondence}

\section{Endang Hanani}

Department of Pharmacognosy and Phytochemistry, Faculty of Pharmacy and Sciences, Universitas Muhammadiyah Prof. DR. HAMKA

JI. Delima II/IV Klender, Jakarta 13460, INDONESIA.

Phone No: +62 811881719 ;

E-mail: hananien@yahoo.com

History

- Submission Date: 12-04-2020;

- Review completed: 01-07-2020;

- Accepted Date: 08-07-2020.

DOI : 10.5530/pj.2020.12.181

Article Available online http://www.phcogj.com/v12/i6

\section{Copyright}

(c) 2020 Phcogj.Com. This is an openaccess article distributed under the terms of the Creative Commons Attribution 4.0 International license.

\section{ABSTRACT}

Background: Ochna kirkii Oliv. belongs to family Ochnaceae is commonly known as "mickey mouse plants" in Asia, included in Jakarta. Objectives: This research was conducted to study the pharmacognosy and total phenolic content. Methods: The pharmacognosy study including the macroscopic, microscopic, fluorescence and phytochemical characteristic, which enable to identification of medicinal plant drug, as well as the total phenolic content using spectrophotometric method. Physicochemical parameters, like loss on drying, ash value, extractive values etc. were also determined following WHO guidelines. Results: Physicochemical standard quantified include total ash $5.15 \% \pm 0.4623$, acid insoluble ash $0.32 \%$ \pm 0.2614 , water soluble ash $10.72 \% \pm 0.2340$, alcohol soluble extractive $12.8 \% \pm 1.3770$, ether soluble extractive $7.30 \% \pm 1.8341$, water content $5.76 \% \pm 0.0050$, loss on drying $6.91 \% \pm$ 1.6133. Preliminary phytochemical screening of the leaves showed the presence of flavonoids, tannins, phenols, saponins and triterpenoid. TLC profile of the $O$. kirkiileaves extracts ( $n$-hexane, DCM, ethyl acetate and 70\% ethanol) showed 8, 6, 7 and 10 spots respectively; in different solvent system. The total phenolic content was $252.08 \mathrm{mg} \mathrm{GAE} / \mathrm{g} \pm 0.4430$. Conclusions: The various macroscopic, microscopic, physical and phytochemical analysis of the O.kirkii leaf is useful in standardization for quality, purity and sample identification.

Key words: Chromatogram profile, Fluorescence, Macroscopic, Microscopic, Ochna kirkii.

\section{INTRODUCTION}

Ochna kirkii is an ornamental perennial shrub or small tree, one species among 86 species of evergreen trees in the genus of Ochna, belongs to the Ochnaceae family. Its species has sinonym Ochna carvalhi, Polythecium carvalhi, Polythecium kirkii, Ochna thomasiana Engl. \& Gilg. Unique flower shaped like a cartoon character of Mickey Mouse is a specific feature of this plant. So, they are generally referred to as 'Mickey-Mouse plants' or 'Ochnas. Several members of this family are cultivated as decorative plants due to their colorful flowers and unusual fruits. ${ }^{1}$ This plant is originally from tropical Africa, but now widely cultivated in tropic countries such Asia and Madagascar. Traditional remedies of Ocnaceae have been recorded in several Asian and Africans countries. For example, the stem bark of O. lanceolata Spreng., a semi-evergreen tree found widely in Central and Peninsular India, is used by the Palliyar tribes as an abortifacient and for treatment of gastric complaints and menstrual disorders. ${ }^{1}$ In Tanzania, Washambaas used $O$. macrocalyx Oliv. bark for treatment of dysmenorrhoea, diarrhea, hemorrhoids, and stomach pain. ${ }^{2}$

Previous phytochemical studies have revealed that the Ochnaceae is a prolific source of complex flavonoids and related phenolic compounds. Reported chemical constituents from the genus Ochna, so far in total ca. 111, include flavonoids, anthranoids, triterpenes, steroids, fatty acids, and a few other compounds and biflavonoids are the predominant constituents within the genus Ochna. Vitexin (apigenin-8-C-glucoside) and isovitexin (apigenin-6-C-glucoside), flavonoid compound that has been proved to give multiple pharmacological effect including anti-cancer ${ }^{3,4}$, anti-oxidant ${ }^{5,6}$, antiinflammatory ${ }^{7,8}$, anti-nociceptive. ${ }^{9}$ Nair et al. isolated vitexin from the acetone-insoluble fraction of the $\mathrm{EtOH}$ extract of O. jabotapita leaves. while isovitexin was obtained from the leaves of O. squarrosa. ${ }^{1}$

On the other hand, research data on the chemical compounds and the traditional used of Ochna kirkii have not been found. Recently, the pharmacognostical studies of Ochna kirkii was carried out. In addition, phenolic level as one of essential compound also explore. This study expected to be useful in the initial data for standardization of its species.

\section{MATERIALS AND METHODS}

\section{Plant collection and authentication}

The leaves, flower and fruits were collected on June 2019 from Duren Sawit area, located in the eastern of Jakarta, Indonesia. The plant was characterized by the Research Centre for Biology, Indonesian Institute of Sciences, (LIPI), Cibinong Bogor Indonesia and voucher specimen was kept in the Pharmacognosy Laboratory, Faculty of Pharmacy and Sciences, UHAMKA University, Jakarta, Indonesia. Plant material were dried at room temperature for 2 weeks in a dry and airy environment. The dried samples were powdered using an electric grinder, then stored in the dark bottle at a dry place until further use. 


\section{Chemical reagent}

Folin-Ciocalteu, gallic acid, were purchased from Sigma Aldrich. Sodium carbonate, $n$-Hexane, dichloromethane, ethyl acetate, ethanol was obtained from Merck Chemical Supplies. All chemicals used were analytical grade.

\section{Pharmacognostical study}

\section{Macroscopic evaluation}

The macroscopic study is the morphological characters/description of the plant parts (leaf, flower, fruit etc.) were observed by naked eye or magnifying lens. Various organoleptic features of $O$. kirkii parts like color, shape, size, odor, taste, surface characteristic and fracture were evaluated.

\section{Microscopic study}

Microscopic of transverse section of fresh leaf, stem and seed was perform. Preparing for powder microscopic of the plants part were observed under the microscope and photographed. The procedure for the microscopic study was described in Indonesian Herb Pharmacopoeia ${ }^{10}$ and Hanani et al. ${ }^{11}$

\section{Extract evaluation}

\section{Extract preparation}

The powdered leaves were extracted using maceration method to determine the phytochemical parameter and total phenolic content. A $500 \mathrm{~g}$ of sample was soaked in $5 \mathrm{~L}$ of $70 \%$ ethanol for $24 \mathrm{hr}$ at room temperature. The mixture was filtered and the residue was extracted again in $3 \mathrm{~L}$ the same solvents and repeated the same procedure. All filtrate combined and concentrated under vacuum rotary evaporator $\mathrm{N}-1200 \mathrm{BS}$ series (EYELA, Shanghai, China) at $40-50^{\circ} \mathrm{C}$ to a yield of $21.25 \%$ of plant extract. This extract stored in air-and water proof containers kept in a refrigerator at $4^{\circ} \mathrm{C}$. From this stock, fresh preparation was made whenever required.

\section{Physicochemical evaluation}

Physicochemical parameters, of the extract was conducted on the determination of moisture content, ash content, acid insoluble ash content, Water-, ethanol- and ether-soluble extractive value. The extract characterization method was performed by standard procedures in Indonesian Herb Pharmacopoeia and WHO guidelines. ${ }^{10,12,13}$ Test samples were run in triplicate.

\section{Phytochemical screening analysis}

Phytochemical analysis of this extract was conducted by screening chemical substances and determination of major compounds. Identification of the presence of phenols, alkaloids, flavonoids, tannins, saponins glycosides, terpenoids were carried out according to the procedures in WHO guidelines ${ }^{6}$, Indonesian Herb Pharmacopoeia ${ }^{10}$, and Dixon and Jena. ${ }^{14}$

\section{Fluorescence character analysis}

Ethanol extract of Ochna kirkii leaves powder was fractionated further with $n$-hexane, dichloromethane (DCM), ethyl acetate and 70\% ethanol. All extracts were concentrated using a rotary evaporator. Leaves powder and all fractions are treated with various chemical reagents. Strong acids, alkalis and organic solvents were added and observed under the daylight and ultraviolet light at $254 \mathrm{~nm}$ and $366 \mathrm{~nm} .{ }^{11,15}$

\section{Thin layer chromatography profile}

All fractions were analyzed for the chromatographic profile using TLC (silica gel $60 \mathrm{GF}_{254}$ ) with different solvents. Each fraction was solved with suitable solvents and spotted using the micro-pipette in the silica plate surface. The plates were developed using a different mobile phase: $n$-hexane-ethyl acetate (9:1), chloroform-methanol (9.5:0.5), methanol - ethyl acetate (1:9), and 100\% ethyl acetate. The dried plate was sprayed with $10 \%$ sulfuric acid/methanol solution, followed by heating at $105^{\circ} \mathrm{C}$ for 5 minutes in an oven, and observed under visible light ${ }^{16}$. The retention factor value was measured and the color was observed.

\section{Total phenolic content}

Total phenol content (TPC) in the ethanol extract of Ochna kirkii leaves was determined using the Folin-Ciocalteu method described by Stankovic (2011) with minor modifications. ${ }^{17}$ The extract was dissolved in distilled water to a concentration of $50 \mu \mathrm{g} / \mathrm{mL}$. The calibration curve was established using gallic acid $(15 ; 25 ; 35 ; 45 ; 55 \mu \mathrm{g} / \mathrm{mL})$. The Dilute extract or gallic acid $(1.6 \mathrm{~mL})$ was added to $0.2 \mathrm{~mL} \mathrm{FC}$ reagent (5fold diluted with distilled water) and mixed thoroughly for 3 minutes. Sodium carbonate $(0.2 \mathrm{~mL}, 10 \% \mathrm{w} / \mathrm{v})$ was added to the mixture and allowed to stand for 30 minutes at room temperature. The absorbance of the mixture at $765 \mathrm{~nm}$ was measured by spectrophotometer UV-Vis UV-1601 series (Shimadzu, Kyoto, Japan). The concentration of total phenolic compound was determined as mg of gallic acid equivalents/ $\mathrm{g}$ of the extract by using an equation obtained from the gallic acid calibration curve. The samples were prepared in triplicate and the mean value of absorbance was obtained.

\section{RESULTS}

\section{Macroscopic and microscopic analysis}

\section{Macroscopic}

Ochna kirkii is a big shrub or a small tree, with a height of 3-5 meters tall (Figure 1). The leaves are dark green color, glossy, alternate, oblongelliptic to narrow-obovate, heart-shape, rounded at the tip, up to 12 $\mathrm{cm}$ long (Figure 2A). Flowers are bright yellow color and vibrant red flower-like calyxes (Figure 2B, 2C, 2D, 2E), as well as green immature fruits and ripe black berries (Figure 2F, 2G, 2H). Each flower is about $4-5.3 \mathrm{~cm}$ in diameter, has 5-petaled single in axillary and terminal clusters and has a cluster of yellow stamens with orange anthers in the center.

\section{Microscopic}

The transverse section of the leaf of Ochna kirkii (Figure 3A) showed cuticula, upper epidermis, palisade, collenchyma, mesophyll and oxalate crystals; Transverse section of stem of O. kirkii (Figure 3B) showed parenchyma, sclerenchyma and calcium oxalate crystals. The

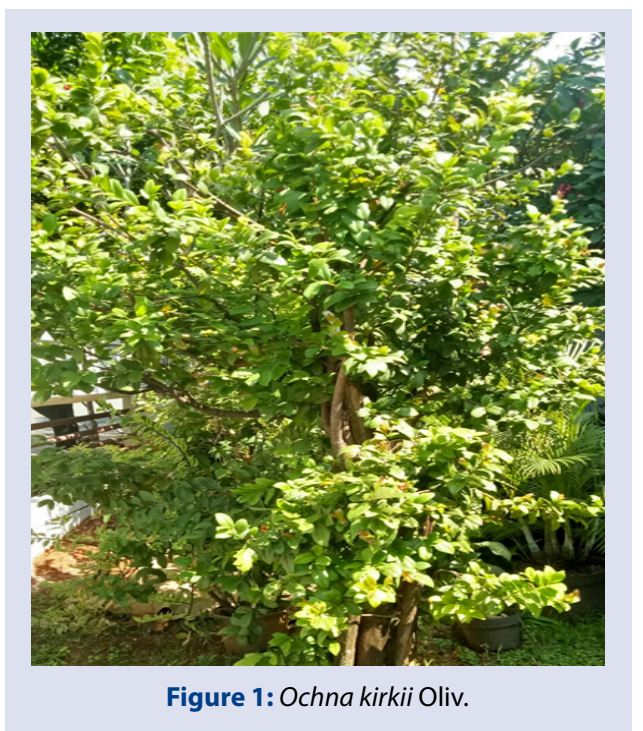


powder of leaves showed parasitic stomata (Figure 4A); glandular hair (4B); calcium oxalate crystals (Figure 4C); collenchyma cell (Figure $4 \mathrm{D}$ ) and vascular bundle (Figure 4E). the flower powder showed parenchyma that contains anthocyanin inside which gives a clear red color (Figure 5A), the seed powder showed oil globules (Figure 5C); starch grains (Figure 5D) and endosperm (Figure 5E).

\section{Physicochemical characteristics}

The physicochemical characteristics such as loss on drying, ash values, water, alcohol and ether soluble extractive, were given in Table 1.

\section{Phytochemical screening}

The preliminary phytochemical screening of the ethanol extract of the leaves of $O$. kirkii were analyzed. Flavonoids, phenols, tannins, saponins, and terpenoids were present in the extract, except the alkaloids.

\section{Fluorescence analysis}

The fluorescence of leaves powder and all fraction were analyzed under daylight, ultraviolet light ( 254 and $366 \mathrm{~nm}$ ) by treatment with different chemical reagents. The results were summarized in Table 2.

\section{TLC chromatography}

The TLC chromatography results (Table 3 ) of the $n$-hexane, DCM, ethyl acetate and, $70 \%$ ethanol extract showed the presence of $8,6,7$, and 10 spots respectively, in different mobile phase system.

\section{Determination of total phenolic content}

The total phenolic content of the extract was determined by FolinCiocalteu methods, and gallic acid was used as the standard. The amount of phenolic content in the extract was presented in Table 4.



Figure 2: A. Leaves; B. Yellow and red flower; C. Yellow flower; D. Red flower with fruits; E. Stem; F. Fruits; G. Young fruits; H. Seed.

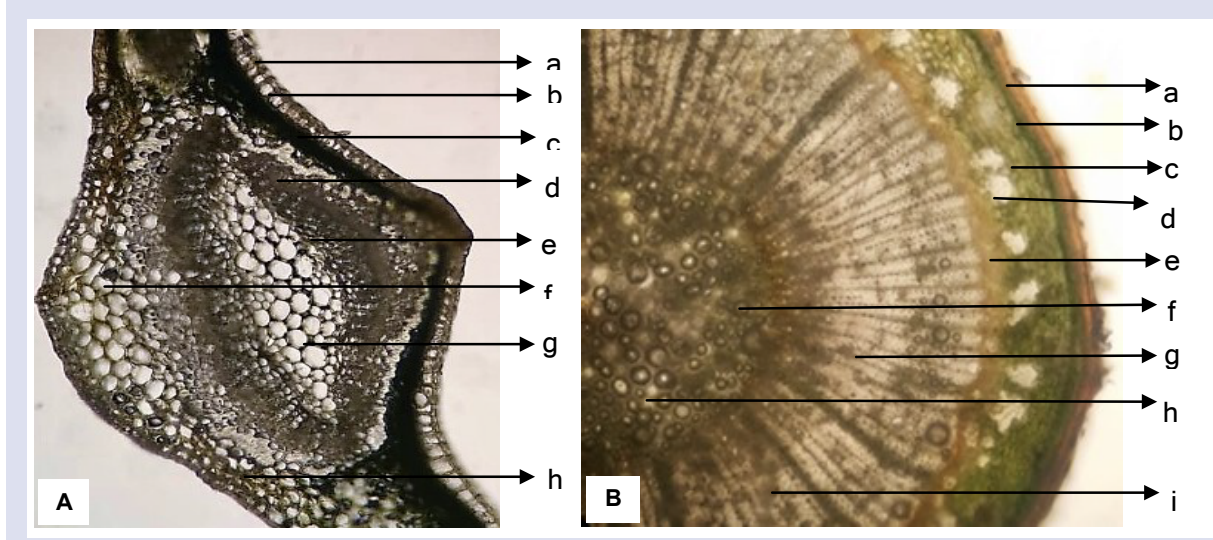

Figure 3: A. Transverse section of leaf: a). Cuticula; b). Upper epidermis; c). Palisade; d). Floem; e). Xylem; f). Collenchyma; g). Mesophyl; h). Lower epidermis.

B. Transverse section of stem: a). Cuticula; b). Epidermis; c). Parenchyma; d). Schlerencyma; e). Floem; f) Xylem; g). Hypodermis; h). Pith; I). Calcium oxalate crystal. 


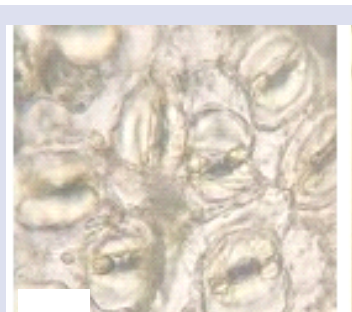

A
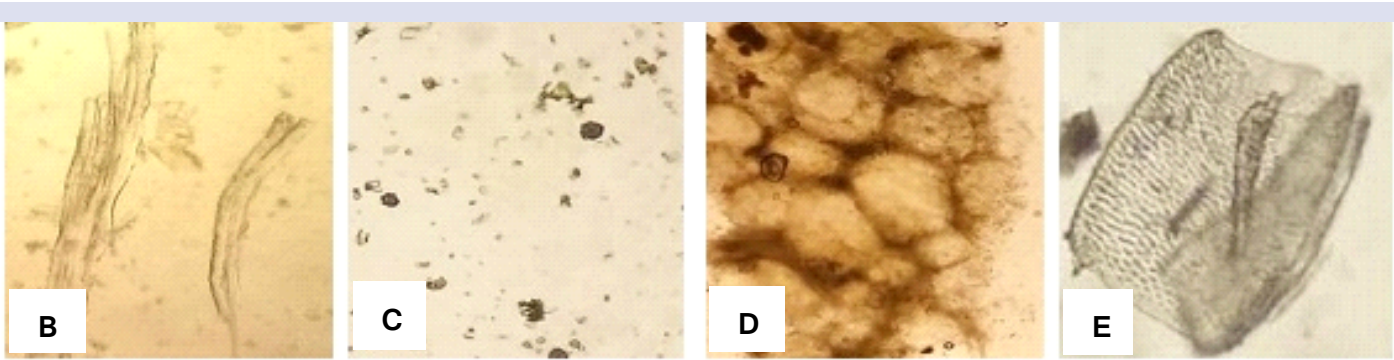

Figure 4: Microscopic of leaves powder: A. Stomata (parasitic type); B. Glandular hairs; C. Calcium oxalate crystals; D. Collenchyma cell; E. Vascular bundle.
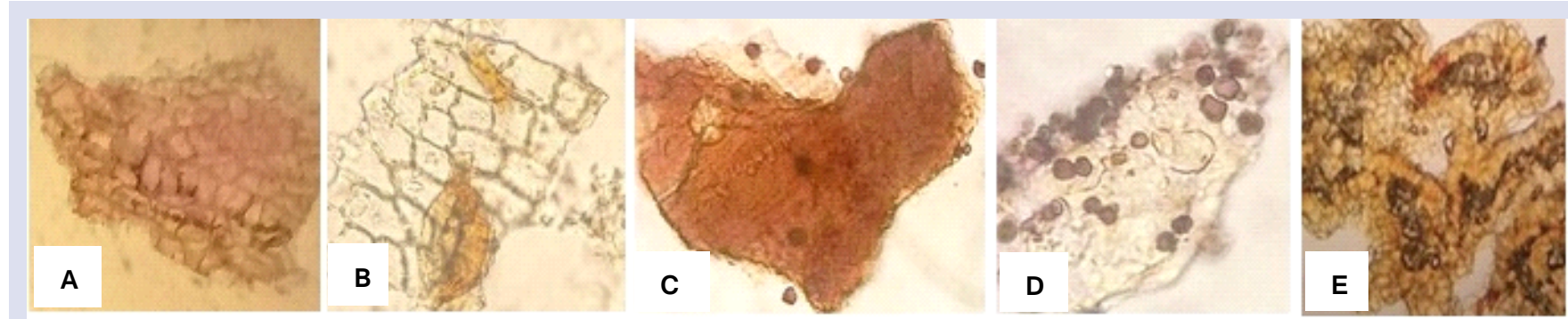

Figure 5: Microscopic of flower powder: A. Parenchyma with anthocyanins inside; B. Epidermis; Seeds powder; C. Epidermis with oil gland; D. Starch grains; E. Endosperm.

Table 1: Physicochemical Parameter of Powder of Ochna kirkii leaves.

\begin{tabular}{cc}
\hline Parameters & Average $(\% \mathrm{w} / \mathrm{w})$ \\
\hline $\begin{array}{c}\text { Moisture content } \\
\text { Loss on drying }\end{array}$ & \\
Water content & $6.91 \% \pm 1.6133$ \\
& \\
Ash Value & \\
a. Total ash & $5.15 \% \pm 0.0350$ \\
b. Water soluble ash & $10.72 \% \pm 0.4623$ \\
c. Acid insoluble ash & $0.32 \% \pm 0.2614$ \\
& \\
& \\
Extractive values & $12.80 \% \pm 1.3770$ \\
a. Alcohol soluble & $10.72 \% \pm 0.9767$ \\
b. Water soluble & $7.30 \% \pm 1.8341$ \\
c. Ether soluble & \\
\hline
\end{tabular}

\section{DISCUSSION}

The macroscopic and microscopic studies of the plant part will enable to identify the crude drug. The microscopic evaluation is one of the simplest and cheapest methods for establishing the correct identification of the sources of the drug material. The moisture content (loss on drying and water content) were not so high, it means gives to suitable condition and eliminated the proliferation of microorganism. ${ }^{10}$ The extractive value of ethanol was found to be highest followed by water and ether. It also helpful in estimation of specific chemical constituents which are soluble in particular solvents. ${ }^{18}$ Ash value determination the inorganic substance and other impurities present in the drug. Ash and extractive value can be used as reliable aid for detecting adulteration. Fluorescence is one of the important methods exhibited by various chemical reagents which show different color in daylight and fluorescence in the UV light. Thus, the fluorescence is used for qualitative assessment of crude drug. ${ }^{19}$ Fluorescence analysis showed the characteristic of extract reacted to reagent used. Chemical compound in plant extract may be often converted into fluorescent derivatives by using different chemical reagents though they are not fluorescent so that this can be used as one of the important qualitative test parameters in plants. ${ }^{20}$ Identification results of secondary metabolite of the extract showed the presence of flavonoids, phenols, tannin, saponins, triterpenoids, while the results could not show any positive indication for alkaloids.

The thin layer chromatographic profile of hexane, DCM and 70\% ethanol extracts were presented with different mobile phase system to determine how many compounds in the three kinds of extract, and each compound has a different $\mathrm{Rf}$ value and color.

Phenols are one class of secondary metabolites in plants. They are known to have antioxidant activity. ${ }^{21}$ Phenolic compounds are known as high-level antioxidants because of their ability to scavenge free radicals and active oxygen species, such as singlet oxygen, superoxide free radicals and hydroxyl radicals. ${ }^{22}$ The total phenolic compounds are one of an important factor in the consideration of antioxidant activity. ${ }^{23}$ 
Table 2: Fluorescence analysis of the $\boldsymbol{O}$. kirkii extracts.

\begin{tabular}{|c|c|c|c|}
\hline Sample/Reagents & Visual & $254 \mathrm{~nm}$ & $366 \mathrm{~nm}$ \\
\hline \multicolumn{4}{|l|}{ Leaves powder } \\
\hline $10 \% \mathrm{NaOH}$ & Yellowish red & Green & Green \\
\hline Dil. $\mathrm{NH}_{4} \mathrm{OH}$ & Yellowish red & Yellow & Yellow \\
\hline Conc. $\mathrm{H}_{2} \mathrm{SO}_{4}$ & Dark brown & Black & Light brown \\
\hline Conc. $\mathrm{HCl}^{4}$ & Yellowish green & Yellow & Dark green \\
\hline Conc. $\mathrm{HNO}_{3}$ & Yellowish red & Yellowish red & Green \\
\hline \multicolumn{4}{|l|}{$n$-hexane } \\
\hline $10 \% \mathrm{NaOH}$ & Yellowish Green & Yellowish red & Yellowish red \\
\hline Dil. $\mathrm{NH}_{4} \mathrm{OH}$ & Light brown & Yellowish red & Yellow \\
\hline Conc. $\mathrm{H}_{2}^{4} \mathrm{SO}_{4}$ & Brownish black & Brownish black & Dark black \\
\hline Conc. $\mathrm{HCl}^{4}$ & Light green & yellow & Greenish black \\
\hline Conc. $\mathrm{HNO}_{3}$ & Yellowish red & Dark green & Light brown \\
\hline \multicolumn{4}{|l|}{ DCM } \\
\hline $10 \% \mathrm{NaOH}$ & Light green & Dark green & Yellowish red \\
\hline Dil. $\mathrm{NH}_{4} \mathrm{OH}$ & Light brown & Light green & Dark green \\
\hline Conc. $\mathrm{H}_{2} \mathrm{SO}_{4}$ & Dark green & Brownish black & Dark black \\
\hline Conc. $\mathrm{HCl}$ & Light green & Yellow & Yellowish green \\
\hline Conc. $\mathrm{HNO}_{3}$ & Yellowish red & Yellowish red & Yellowish green \\
\hline \multicolumn{4}{|l|}{ Ethyl acetate } \\
\hline $10 \% \mathrm{NaOH}$ & Yellowish brown & Brown & Brown \\
\hline Dil.NH4OH & Brown & Brown & Brown \\
\hline Conc.H2SO4 & Dark brown & Yellow & Brownish black \\
\hline Conc. $\mathrm{HCl}$ & Yellow & Light yellow & Light yellow \\
\hline Conc.HNO3 & Red & Dark brown & Light brown \\
\hline \multicolumn{4}{|l|}{$70 \%$ Ethanol } \\
\hline $10 \% \mathrm{NaOH}$ & Light brown & Dark brown & Black \\
\hline Dil. $\mathrm{NH}_{4} \mathrm{OH}$ & Brown & Brown & Brown \\
\hline Conc. $\mathrm{H}_{2} \mathrm{SO}_{4}$ & Dark brown & Brown & Brown \\
\hline Conc. $\mathrm{HCl}$ & Yellowish brown & Light brown & Greenish yellow \\
\hline Conc. $\mathrm{HNO}_{3}$ & Greenish brown & Brown & Dark black \\
\hline
\end{tabular}

Table 3: TLC Profile of different extract of O.kirkii.

\begin{tabular}{|c|c|c|c|c|}
\hline Extract & Solvent system & No. of spot & Spray reagent $\left(10 \% \mathrm{H}_{2} \mathrm{SO}_{4}\right.$ Methanol) & $R_{f}$ \\
\hline$n$-Hexane & $\begin{array}{c}n \text {-Hexane--ethyl acetate } \\
(9: 1)\end{array}$ & 8 & $\begin{array}{l}\text { Brown; Green } \\
\text { Green; Green } \\
\text { Light violet; Grey } \\
\text { Pink; Grey }\end{array}$ & $\begin{array}{ll}0.02 & 0.15 \\
0.25 & 0.49 \\
0.60 & 0.82 \\
0.89 & 0.97\end{array}$ \\
\hline DCM & $\begin{array}{c}\text { Chloroform-- } \\
\text { Methanol (9.5:0.5) }\end{array}$ & 6 & $\begin{array}{l}\text { Violet; Light violet } \\
\text { Violet; Green } \\
\text { Light blue; Green }\end{array}$ & $\begin{array}{l}0.170 .30 \\
0.470 .56 \\
0.770 .90\end{array}$ \\
\hline Ethyl acetate & Ethyl acetate $100 \%$ & 7 & $\begin{array}{l}\text { Brown; Violet } \\
\text { Brown; Light brown } \\
\text { Violet; Light yellow } \\
\text { Light green }\end{array}$ & $\begin{array}{c}0.350 .43 \\
0.580 .70 \\
0.760 .78 \\
0.88\end{array}$ \\
\hline $70 \%$ Ethanol & $\begin{array}{l}\text { Methanol--ethyl acetate } \\
(1: 9)\end{array}$ & 10 & $\begin{array}{c}\text { Light brown; Brown } \\
\text { Brown; Light Brown } \\
\text { Brown; Grey } \\
\text { Green; Violet } \\
\text { Green; Violet }\end{array}$ & $\begin{array}{l}0.170 .29 \\
0.350 .38 \\
0.440 .55 \\
0.570 .68 \\
0.770 .85\end{array}$ \\
\hline
\end{tabular}

Table 4: Total phenolic content in the $70 \%$ ethanol extract of 0 . kirkii.

\begin{tabular}{cccc}
\hline Concentration of plant extract $(\mu \mathrm{g} / \mathrm{mL})$ & Absorbance & mg of GA/g extract & 251.89 \\
25.1889 & 0.356 & 252.59 & Mean \pm SD \\
25.2711 & 0.357 & 252.76 & $252.08 \mathrm{mg} \mathrm{GAE} / \mathrm{g} \pm 0.4430$ \\
25.1889 & 0.356 & \\
\hline
\end{tabular}


The results in this study have shown in the $70 \%$ ethanol extract exist $252.08 \mathrm{mg} \mathrm{GAE} / \mathrm{g}$ extract of phenolic compound, it can be assumed that the extract have antioxidant activity.

\section{CONCLUSION}

Specific characteristics of a plant especially those that are beneficial in medicine are very important to be observed so that the falsification of this plant can be prevented. The pharmacognostical evaluation for the Ochna kirkii are laid down for the first time in this study. The present research are helps in setting the standards for proper identification, authentication and also for the standardization of crude drugs material. Herbal manufactures can utilize them for selection and identification of the raw material for drug production. The recent study showed that Ochna kirkii Oliv. has a significant phenolic level, it is necessary to evaluate the antioxidant and the specific pharmacological activity for further study.

\section{CONFLICTS OF INTEREST}

All authors declare that they have no conflicts of interest.

\section{ACKNOWLEDGEMENT}

The authors are gratefully to Dr. apt. Hadi Sunaryo, M.Si., Dean of the Faculty and Pharmaceutical Sciences, Universitas Muhammadiyah Prof. DR. HAMKA, Jakarta Indonesia

\section{REFERENCES}

1. Bandi AKR, Dong UL, Raphael GT, Duvvuru G, Bernard B. Phytochemical and Biological Studies of Ochna Species. Chemistry and Biodiversity. 2012;9:251270.

2. Schlage C, Mabula C, Mahunnah RLA, Heinrich M. Medicinal Plants of the Washambaa (Tanzania): Documentation and Ethnopharmacological Evaluation. Plant Biol. 2000;2: 83-92.

3. Choi HJ, Eun JS, Kim BG, Kim SY, Jeon H, Soh Y. Vitexin, a HIF-1alpha inhibitor, has anti-metastatic potential in PC12 cells. Mol Cell. 2006;22(3):291-9.

4. Yang SH, Liao PH, Pan YF, Chen SL, Chou SS, Chou MY. The novel p53dependent metastatic and apoptotic pathway induced by vitexin in human oral cancer OC2 cells. Phytotherapy Research. 2013;27(8):1154-61.

5. Zhang J, Yuan K, Zhou WL, Zhou J, Yang P. Studies on the active components and antioxidant activities of the extracts of Mimosa pudica Linn. from southern China. Pharmacogn Mag. 2011;7(25):35-9.

6. An F, Yang G, Tian J, Wang S. Antioxidant effects of the orientin and vitexin in Trollius chinensis Bunge in D-galactose-aged mice. Neural Regen Res. 2012;7(33):2565-75.
7. Rosa SI, Rios-Santos F, Balogun SO, Martins DT. Vitexin reduces neutrophi migration to inflammatory focus by down-regulating pro-inflammatory mediators via inhibition of p38, ERK1/2 and JNK pathway. Phytomedicine: International J of Phytotherapy and Phytopharmacology. 2015;23(1):9-17.

8. Lin CM, Huang ST, Liang YC, Lin MS, Shih CM, Chang YC, et al. Isovitexin suppresses lipopolysaccharide-mediated inducible nitric oxide synthase through inhibition of NF-kappa B in mouse macrophages. Planta Med. 2005;71:748-53.

9. Borghi SM, Carvalho TT, Staurengo-Ferrari L, Hohmann MSN, Pinge-Filho P, Casagrande $\mathrm{R}$, et al. Vitexin inhibits inflammatory pain in mice by targeting TRPV1, oxidative stress, and cytokines. J Nat Prod. 2013.76(6):1141-9.

10. Anonymous. Farmakope Herbal Indonesia. Ed I. Ministry of Health of the Republik of Indonesia. Jakarta, Indonesia; 2008.

11. Hanani E, Soewandi SHW, Hayati, Revita N. Pharmacognostical and preliminary phytochemical evaluation of Cordia sebestena L. Pharmacognosy Journal. 2019;11(5):1100-5.

12. Aher AN, Kavita B, Sunanda M, Shubhangi B. Pharmacognostic, phytochemical and pharmacological investigation on leaf and root of Mirabilis jalapa Linn. (Nyctaginaceae). Int J Pharm Sci Rev Res. 2016;40(2):132-6.

13. World Health Organization. Quality control methods for medicinal plant materials. WHO Library, Geneva: 1998;1-115.

14. Dixon D, Jeena G. Comparison of Different Solvents for Phytochemical Extraction Potential from Datura metel Plant Leaves. International Journal of Biological Chemistry. 2016;11(1):17-22.

15. Kokoski CJ, Kokoski RJ, Sharma M. Fluorescence of powdered vegetable drugs in ultra violet radiation. Journal of the American Pharmaceutical Association. 1958;47(1):715-7.

16. Sherma J, Bernard F, editors. Handbook of Thin Layer Chromatography: 3rd ed New York: Basel: Marcel Dekker Inc.; 2003.

17. Stankovic MS, Neda F, Marina T, Slavica S. Total Phenolic Content, Flavonoid Concentrations and Antioxidant Activity, of the Whole Plant and Plant Parts Extracts from Teucrium montanum L. Var. Montanum, f. Supinum (L.) Reichenb. Biotechnology and Biotechnological Equipment. 2011;33:63-72.

18. Kulkarni YA, Gokhale SB, Yele SU, Surana SJ, Tatiya AU. Pharmacognostical studies and preliminary phytochemical investigations on the bark of Persea macrantha (Nees) kosterm not tilted. Indian Journal of Natural Products and Resources. 2011;2(2):211-7.

19. Menpara D, Chanda S. Phytochemical and pharmacognostic evaluation of leaves of Pongamia pinnata L. (Fabaceae). Pharmacognosy Communications 2014;4(2):3-7.

20. Gayathri, D Kiruba. Fluorescence Analysis Of Two Medicinal Plants - Psidium guajava L and Citrus aurantium. International Journal of Pharmaceutical Sciences and Research. 2015;6(3):1279-82.

21. Harborne JB. A Guide to Modern Techniques of Plant Analysis. Phytochemical Methods. 1998. Chapman \& Hall, London. 60.

22. Naczk M, Shahidi F. Extraction and analysis of phenolics in food. J Chromatogr 2004;1054:95-111.

23. Sreeja S, Raphael RK. Qualitative and quantitative phytochemical analysis and DPPH radical scavenging activity of different extracts of flower of Bauhinia acuminate Linn. Int J Curr Pharm Res. 2017;9(6):23-6. 


\section{GRAPHICAL ABSTRACT}

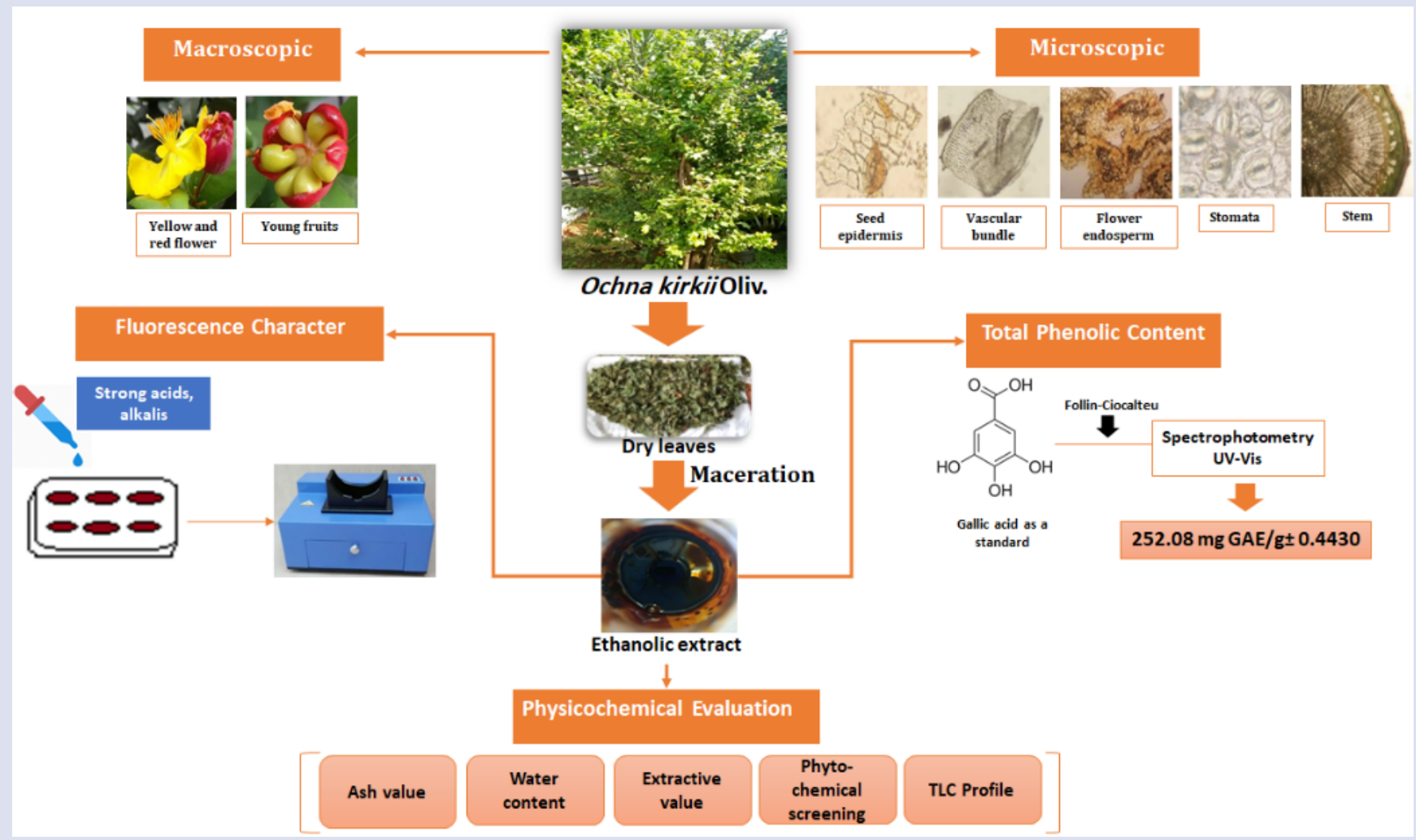

\section{SUMMARY}

- The present research are helps in setting the standards for proper identification, authentication and also for the standardization of crude drugs material.

- The pharmacognostical evaluation for the Ochna kirkii are laid down for the first time in this study.

- Ochna kirkii Oliv. has significant phenolic level and it can be assumed that the extract have antioxidant activity.

\section{ABOUT AUTHORS}

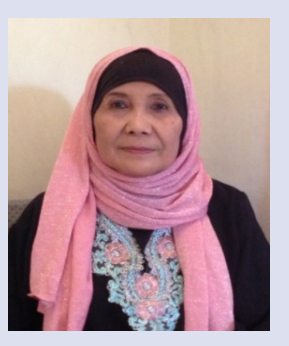

Endang Hanani: Researcher and lecturer at Faculty of Pharmacy and Sciences, University of Muhammadiyah Prof. DR. HAMKA Jakarta. Also as Professor of Pharmacognosy and Phytochemistry.



Vivi Anggia: Researcher and lecturer at Faculty of Pharmacy and Sciences, University of Muhammadiyah Prof. DR. HAMKA Jakarta. 


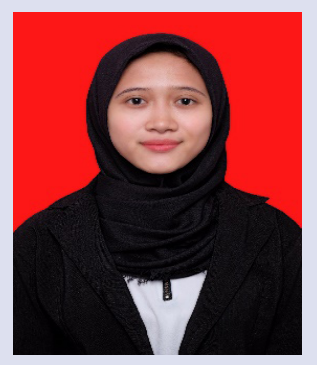

Ike Nurvita Amalina: Graduate student at Faculty of Pharmacy and Sciences, University of Muhammadiyah Prof. DR. HAMKA Jakarta.

Cite this article: Hanani E, Anggia V, Amalina IN. Ochna kirkii Oliv: Pharmacognostical Evaluation, Phytochemical Screening, and Total Phenolic Content. Pharmacogn J. 2020;12(6):1317-24. 